\title{
BASIN ÖZGÜRLÜĞÜ VE OSMANLI DEVLETI'NDEKI GÖRÜNÜMÜ
}

\author{
Dr. Nevin ÜNAL ÖZKORKUT
}

\section{I-Basın Özgürlüğï}

\section{A. "Basm Özgürlüğü" ve "İletişim Özgürlüğü" Kavramları}

Düşünceyi açıklama özgürlüğünün bir kullanım biçimi olan basın özgürlüğü, haberlerin, düşünce ve kanaatlerin izne ve sansüre tâbi olmaksızm basın' yolu ile serbestçe yayılabilmesi olarak tanımlanabilir. Zaman içerisinde haberlerin, dusşünce ve kanaatlerin radyo, televizyon (bunlara yakın geçmişte internet de eklenmiştir) gibi basın dışındaki kitle iletişim araçları ile de yayılabilmesi sonucunda hepsini içeren bir üst kavram olarak "iletişim özgürlüğ̋̈u" tercih edilmiştir. ${ }^{2}$ Öte yandan, esas itibariyle basın özgürlügüünün, okuyucunun haber alma hakkını da içerdiğ̣i kabul edilmekle birlikte, basın özgürlügünün basına özgü bir özgürlügüu ifade ettiģ

* Ankara Úniversitesi Hukuk Fakültesi Hukuk Tarihi Anabilim Dalı

" "Bası", geleneksel jfadesini gazete, dergi gibi dönemsel yayınlarda bulmakla birlikte, sadece bunları değil, tüm basılmış (kitap vs.) eserleri de içermektedir. Martin Löffler, Presserecht, Kommentar, München und Berlin 1955, s.9; Kayıhan İçel, Kitle Haberleşme Hukuku, İstanbul 1998, s.107: Ayrıca bkz.,Ahmet Kzlıçoğlu, Şeref Haysiyet ve Özel Yaşama Basın Yoluyla Saldırılardan Hukuksal Sorumluluk, Ankara 1982, s.16; Buna bağlı olarak "basın ozzgưrlüğíi” de, yalnızca dönemsel yayınları değil tüm basılmış eserleri kapsayan bir içeriğe sahiptir. (1982 Anayasası'ntn. basın özgürlüğünü düzenleyen 28.maddesinde, süreli ve süresiz yayınlar ayırımı yapılmış: 29 maddesinde ise süreli ve süresiz yayın hakkı düzenlenmiştir. 1 maddesinde, basının serbest olduğu ve basılmış eserlerle bunların neşrinin bu kanun hükümlerine tâbi olduğu ifade edilen Basın Kanunu'nun, 2.maddesinde de "bu kanun hükümlerine göre basılmış eserlerden maksat, neşredilmek üzere tabı aletleriyle basılan veya sair her türlui vasıtalarla çoğaltılan yazılar ve resimler gibi eserlerdir" hükmü yer almaktadır.)

Çalışmamtzda "basın özgürlüğü”, -özellikle Osmanlı Devteti’ndeki gelişmelerde- esas itibariyle gazete ve dergi gibi dönemsel yayınlar açısından inceleımiştir.

: İçel, s.21-22. Ayrıca bkz.. Sulhi Dönmezer, Basın Hukuku, İstanbul 1968, s.14; Nermin Abadan, "Basın ve Haberleşme Hürriyeti". Türkiye'de Insan Hakları Semineri (9-1 ] Arahk 1968), Ankara 1970,s.89-9] ve 122; Ibrahim Ö. Kaboğlu, Özgürlükler Hukuku İnsan Haklarının Hukuksal Yapısı Üzerine Bir Deneme, İstanbul 1994, s.274-275. 
ve basın dışındaki bireyleri kapsamádığ gerekçesiyle bu kavram yerine iletişim özgürlüğgunün kullanılması gerektiğini savunan görüşler de bulunmaktadir.

\section{B- Basmm Önemi}

İfade özgürlüğünü kullanabilmenin önemli bir aracı olan basın. başlangıcından günümüze değin özellikle siyasal yaşam alanında olmazsa olmaz niteliğini korumuştur. İlkeli ve sorumlı bir yayımcılı yapmak kaydıyla basın, devlet otoritesini sınırlayan ve bireylerin özgürlüklerini koruyan bir faktör olarak, zaman zaman bu amaçlara yönelik diğer bir çok etkenden ve kurumdan daha başarılı olabilmekte ve bu nedenle yasama. yürü̈tme ve yargı erklerinin yanı sıra "dördüncü kuvvet" kabul edilmektedir. Devlet iktidarının sımırlanmasının etkili bir aracı olarak düşünülen kuvvetler ayrilığının, günümiiz parlamenter sistemlerinde özellikle yasama ve yürütme erkleri açısından klasik anlamından uzaklaşması, basının aynı amaca yönelik rolünün önemini ortaya koymakta ve bir kuvvet olarak nitelendirilişini daha anlamlı kılmaktadır. Özgürlüklerin er. başta gelen güvencelerinden biri olan kamuoyunun oluşumunda önemli rol oynayan basın, yönetenler ile yönetilenler arasında sürekli bir iletişim ve denetim organıdır. ${ }^{4}$ Okuyucuyu devlet politikaları, iktidarın icraatları hakkında bilgilendirdiği gibi, bireylere de kendisi aracılığıyla düşüncelerini ifade etme olanağı sunabilir ${ }^{5}$ ve bu şekilde de yönetenin yönetilene karşı sorumluluk hissetmesini sağlar.

\section{C- Basın-Demokrasi İlişkisi ve Demokratik Yönetim Usullerinin Basın Özgürlü̆ği Açısından Önemi}

Yukarıda ifade edilen başlıca işlevler, basını modern bir demokrasi anlayışının önemli ve zorunlu unsuru haline getirmektedir ve her biri basının, kamu yararı adına yerine getirmesi gereken önemli bir görevidir. Nasıl basın, demokrasinin olmazsa olmazı ise bu görevlerin basın tarafından yerine getirilebilmesi için de demokrasi, olmazsa olmaz nitelik taşır, önemli ve zorunlu bir unsur olarak kendisine gereksinim duyulur. Gerçi bir başka siyasal yapı içerisinde de basın, sesini çıkarabildiği ölçüde demokrasiye

"Oktay Ekşi, “" 'Basın Özgürlüğü’ Diye Bir Kavram Yoktur”, Yeni Türkiye, 96/11. s.251. Benzer şekilde bkz., Roger Pinto’dan ıleten. Dönmezer, Basın Hukuku.s.14 .

¿ Münci Kapani. Kamu Hürriyetleri, Ankara 1993,s.267-269 ve Münci Kapani. Politika Bilimine Giriş. Ankara 1988,s.150-151; David Beetham-Kevin Boyle, Demokrasinin Temelleri, Çeviren:Vahit Bıçak. Ankııra 1998,s.11-12; Ferdinand Tönnies, Kritik der öffentlichen Meinung, Berlin 1922 den ileten, John Keane, Medya ve Demokrasi. Çeviren: Haluk Şahin. İstanbul 1999. s.42-43. Martin Löfler-Reinhart Ricker. Handbuch des Presserechts. München 2000,s.38; Löfflet.s.4 vd.; İ̧el.s.99vd.;Demokrasi Nedir? Türk Demokrasi Vakfi, Ankara 1992, s.65.

${ }^{5}$ Demokrasi Nedir? s.65 
duyulan özlemi dile getirip, bir özgürluik ve demokrasi mücadelesi verebilir. Ancak, basını bu işlevleri gerçek anlamda yerine getirebilmesi için "özgür" olması gerekir ve demokratik olmayan bir duizen içerisinde basın özgürlü̈üinden bahsetmek güçleşir. Mutlakiyetçi ve totaliter devletlerin tarihi, bunu dogrular niteliktedir. Nitekim mutlakiyetçi devlet anlayışının benimsendiği yerlerde, basının hükümdarı ya da siyasetini eleştirmesi yasaklanmı̧; totaliter rejimlerde ise basın, iktidarm hizmetindeki bir araç olarak kabul edilmiştir. ${ }^{6}$ Oysa ki demokratik bir yapı içinde basın, bireyin siyasi kararlar üzerinde etkili olabilmesi ve siyasal katılımı için gerekli olan haber alma hakkını kullandığı önemli bir araç olarak, demokrasiyi sadece yönetenleri halkın seçtiği bir rejim olmaktan çıkarır; demokratik usullerin sağladı̆̆ı çoğulculuğa dayalı avantajları değerlendirmek suretiyle demokrasi içinde doğabilecek riskleri azaltabilir. Yani demokrasi ve basın birbirinin güvencesi ve tamamlayıcısıdır. Ancak, bu cümlenin teori alanından demokratik devletler pratiğine aktarıldı̆̆ında kesinliğini yitirebileceği göz ardı edilmemelidir. Çünkü, demokratik rejimlerde de gerek siyasi iktidar, gerek sorumluluktan ve etik değerlere bağlıhktan uzak bir iletişim anlayışı, basın özgürlügüünü engelleyebilir. ${ }^{7}$ Öte yandan basın özgürlügüünün, en iyi şekilde demokratik rejim içinde sał̆lanacă̆ı ileri süruiltürken, tüm çă̧daş dernokrasilerde bu özgürlüĭgün să̆lanmasının tek bir ölçüsü bulunmadığını; demokratik usullerle yönetilen iki ayrı devlette, basın özgürlüğünün kapsamının farklı olabileceğini kabul etmek gerekir.

\section{D- Basın Özgürlïğüinün Unsurları}

Basın özgürlüğgu, bașın açısından habere ulaşma ve toplama, düşünce ve kanaatleri açıklama ve tüm bunları yayabilme, okuyucu açısından ise haber alma serbestisini içermektedir. Basın özgürlüğünün birbirini tamamlayan iki ana boyutu bulunmaktadır. Birincisi, basının siyasi iktidar karşısında özgür olması, digeri -ve en az birincisi kadar önemli olanı- ise basının kendi içindeki özgürlügüüdür.

Gelişim süreci itibariyle basın özgürlüğünden ilk anlaşılan, basının siyasi iktidar karşısında bağımsız olması gerektiğiđir. Başlangıçta bu özgürlüğün tek engeli devlet olarak görülmüş ve devletin tamamen tarafsız ve pasif olması arzulanmıştır. Günümüzde ise basının siyasi iktidar karşısındaki durumu bu eski liberal söylemden farklıdır. Artık iletişim özgürlüğünün gerçekleşmesi ve gelişmesi için devletin tamamen tarafsız

\footnotetext{
${ }^{6}$ lletişim özgürlủ̆ğünün, de ğişik siyasi rejimler açısından sergilediği farklı görünüme ve bu özgürtüukle ilgili felsefi görüşlere ilişkin geniş bilgi için bkz., Abadan, s.9]-95; Iç̣el, s.23 vd.

${ }^{7}$ Günümüzde demokratik rejimlerin iletişim özgürlüğü alanında yaratabileceği risklere dair bkz., Keane, s.98-114.
} 
kalması yetejli görülmeyerek ondan aynı zamanda aktif önlemler alması beklenmekte, basın özgürlüğü sosyal hak olarak kabul edilmektedir. ${ }^{\text {. Buna }}$ göre, siyasi iktidar basının habere ulaşma ve haberi yayma, diişünce ve kanaatleri açıklama, okuyucunun ise haber alma hakkını engellememeli ve bunları engelleyecek etkenleri önleyici tedbirler almalıdır. Basın vatandaşın haber alma hakkına yönelik talebini yerine getirmediği takdirde siyasi iktidar devreye girmeli ve bireyi korumalıdı. Siyasi iktidar ile basın arasmdaki ilişkinin bu şekilde anlaşılması, iletişimı özgürlügünün sağlanması açısından son derece önemli bir faktör olan basında çoğulculuğun da güvencesini oluşturmakta ve böylelikle basının kendi içindeki özgürlüğuinü de garanti altına almaktadır.

Basının kendi içinde özgür olması ile anlatılmak istenen ise habere ulaşma ve yayma, düşünce ve kanaatleri açıklama hakkının -ki bunlar yukarıda da değinildiği gibi hak olduklanı kadar aynı zamanda görevdir- tüm basın çalışanları zeminine yayılması: bïyük sermayenin eline geçmemesi, tekelleşmemesidir. Basm özgürliuğinni tehlikeye düşüren tekelleşme durumunun baş göstermesiyle basın, kendisini demokrasinin önemli bir unsuru yapan amaç ve görevlerinden uzaklaşır, kâr esas amaç olarak tüm diğer değerlerin önüne geçebilir.

Tekelleşme yoluyla, ifade özgürlügüünün basın aracılığıyla kullanılması olanağına sınırlı sayıda kişi ulaşı ve zamanla gazete çalışanları tek bir politikanın sözcüsü durumuna düşe::ler yani ifade ve basın özgürlüğü smırlanmış olur." Böyle bir durum aynı zamanda okuyucunun haber alma, farklı düşünce ve kanaatlere serbestçe ulaşabilme hakkını da kısıtlar veya ortadan kaldirır. Okuyucu, haberlere, olaylar hakkındaki yorum ve eleştirilere arzuladığı geniş çerçevede ulaşamaz, bunları hep belli grup ya da grupların hatta bazen bir tek kişinin penceresinden görmek zorunda bırakılır ve daha da kötüsü bir süre sonra okıduklarının herkes için doğru olduğu şeklinde bir sabit fikre kapılabilir. ${ }^{10}$ Ozetle, ne okuyacağına birey kendisi karar vermez, buna karar veren basın alanında da gücï elinde tutan büyük sermaye sahibi ya da sahipleridir ki, bu durum en az devlet sansürü kadar yıkıcı etkileri olan bir tür sansürden başka bir şey değildir ${ }^{\prime \prime}$. Tüm bu

\footnotetext{
${ }^{\kappa}$ Dönmezer, Basın Hukuku, s.56-58; Sulhi Dönmezer, "Yine Basın Özgürlügüü Uzerine”. Yeni Türkiye. $96 / 11$,s.248; Abadan,s.74; Içel,s.27 ve53.

${ }^{9}$ Hıfzı Topuz. "Basında Tekelleşmeler", Türk Basınının Beş Sorunu, İstanbul 1989. s.33-34.

${ }^{10}$ Basın alanında tekelleşmenin olumsużłukları hakkında geniş bilg̣i için bk $\%$. Ahmet Danışman. Basın Özğürłügünün Sağlanması Önlemleri, (Devletin Basın Käşşsındaki Akrił Tutumu), Ankara 1982, s.59-65; Çetín Özek. Basın Özgürlüğünden Bilgilenme Hakkıná. Istanbul 1999. S. $547 \mathrm{vd}$.

"Iletişitn alanındaki pazar rekabetinin, tekellere izin vermek, seçenckleri sınırlatnak gibi yollarła iletişim özgürlü̊̆̈unú sımırladığını: sansürün sadece devlet tarafindan kullanılan

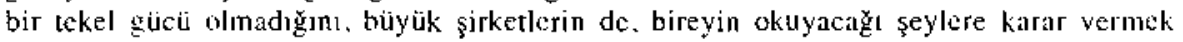


nedenlerle basın özgürlüğünün sağlanabilmesi için tekelleşmenin önüne geçecek etkili tedbirlerin alınması gerekir.

Basın özgürlüğünün zedelenmemesi için zorunlu olan bìr diğer husus, basında özdenetimin sağlanmasıdır ve bu da adalet, gerçeklik, objektiflik ve doğruluk gibi mesleki etik kuralların benimsenmesiyle gerçekleşir. ${ }^{12}$ Basın, habere ulaşmanın ve bunu okuyucuya aktarmanın kendisi için sadece bir hak değil, aynı zamanda görev olduğunu unutmamalıdır. Basında özdenetimin gerekliligi, basının her türlüi sorumluluktan uzak biçimde haber verme özgürlüğü bulunduğu şeklindeki düşünceden farklı olarak, basının bireye ve topluma karşı sorumlu olduğu fikrini ön plana çıkarır. ${ }^{13}$ Basın özgürlüğùntün herhangi bir düzenlemeyle belirtilmemiş olsa bile kendi doğasından kaynaklanan önemli bir sınırı, yani kişilik haklarının korunması açısından da son derece önemli ve zorunlu olan kendi kendini denetim, basinin özgürlügünü kötüye kullanmaması, böylelikle siyasi iktidardan gelebilecek yasal yaptırımlara karşı kendini koruması ve kamuoyu karşısında saygınlığını ve güvenilirliğini sürdürmesi için gereklidir. ${ }^{14}$

\section{E-Basın Özgürlügüunün Düzenlenmesi ve Smırlanması Sorunu}

Basın özgürlügü, bireyin en temel ve vazgeçilmez haklarının başında gelen ve demokrasinin temel dayanağı olarak kabul edilen ifade özgürliugünün ${ }^{15}$ bir kullanım şekli, bu özgürlụ̈üun gerçekleşmesinin önemli

suretiyle sansür mekanizmasını işletciğini ifade eden Keane'nin bu konudaki görüşleri için bkz.. Keane, s.60-97.

${ }^{12}$ Bu konuda bkz, Güliz Úluç, "Basın ve Etik". İstanbul Öniversitesi Iletişim Fakültesi Dergisi, Sayı: $11,2001, \mathrm{~s} .84$.

${ }^{13}$ Başlıca John Milton, John Erskine, Thomas Jefferson ve John Stuart Mill tarafından savunular ve basının okuyucu karşısında sorumlu olmadığı bir basın özgürlïğü öngören fikirlerden farklı olarak, $1956^{\prime}$ da Theodore Peterson tarafından geliştirilmiş olan Toplumsal Sorumluluk Kuramı'na göre. basın topluma karşı sorumludur. Vedat Demir. Türkiye'de Medya ve Özdenetimi. Ístanbul 1998,s.16-17.

${ }^{14}$ Sulhi Dönmezer, "Basinda Oto-Kontrol", İstanbul Universitesi Hukuk Fakültesi Mecmuası, Citt:34, 1969, s.3-6; Demir.s.21 ve 33. Basının kendi kendini denetimi, bizzat basın tarafından oluşturulan gönúllü kurulış̧az eliyle gerçekleştiği gibi yasayla kurulan kuruluşlar tarafından da gerçekleştirilebilmiştir. Dönmezer, "Basında Oto-Kontrol",s. 7-9; İçel s.s.213.; Demir, s.21vd.; Ülkemizde bașında oto-kontrolü sağlamak amacıyla ilk olarak 1960 'da Basın Şeref Divanı. 1988'de ise Basın Konseyi kurulmuştur. Geniş bilgi için bkz., İçel s. 216vd.

Basında özdenetim biçimleri hakkında geniş bilgi için bkz., Demir, s.25vd.

${ }^{15}$ Dahl, geniş ölçekli bir demokrasinin hangi politik kurumlara ihtiyacı vardır sorusuna verdiği altı cevap arasında üçüncü sırayı ifade özgürlfỉ̆üne, dördüncü strayı ise alternatif bilgilenme kaynaklarına vermekte ve ba iki unsurun, etkin katılım, bilgilenme ve gündemin kontrolü şektindeki üç demokratik kriteri yerine getirmek açısından gerekli olduğunu vurgulamaktadir. Robert A.Dahl, Demokrasi Üstüne. Çeviren:Betü Kadıoğlu. Ankara 2001 s.89 ve 96; Dahl'ın saymış olduğu bu şartlar için ayrıca bkz., Philippe C.SchmitterTerry Lynn Karl, “Demokrasi Nedir...Ne Deł̧ildir”, Çeviren:Levent Gönenç, Demokrasinin 
bir aracıdır. Bu nedenle de tıpkı kavnağ̆ını oluşturan bu özgürlük gibi kapsamı üzerindeki tartışmalar her zaman tazeliğini, güncelliğini korumaktadır. Tartışmaların ağırlık noktasını ise bu özgürlük biçiminin mutlak bir sınırsızlık içinde düşüinülemeyeceği; kullanılabilmesi için anayasal givenceye kavuşturulmasının ve gerek dışarıdan gerek kendi içinden gelebilecek kötüye kullanılına tehlikesinin önlenebilmesi için düzenlenmesinin gerekli oldugu ${ }^{16}$ hususundan ziyade düzenlemenin nasıl ve neye göre yapılacağı ve ölçüsuinüun ne olacağı oluşturmaktadır.

Basın özgürlügüüe yer veren ilk metinlerden biri olan 1776 tarihli Virginia Haklar Bildirgesi'nde, basın özgürlüğünün, diğer özgürlüklerin en büyük savunucularindan biri olduğı ve ancak despotik yönetimlerce sınırlanabilecey̆i dile getirilmiştir. Sadece Fransızların değil tiim insanlığın haklarını açıklamayı hedef edinen ve gerek basın özgürlüğï gerek kaynağını oluşturan ifade özgürlüğüinü ilân etroek suretiyle daha sonraki bir çok anayása ve belgeye örnek olan 1789 tarihli Fransız Insan ve Vatandaş Hakları Bildirgesi'nin 11. maddesinde ise düşünce ve görüşlerin özgürce iletişimi kişinin en önemli hakları arasında sayılmış; ancak yasayla belirlenmiş durumlarda bu özgürlüğüun kötüye kullanımından sorumlu olunacağı da ifade edilmiştir.

Basın özgürlïğünü savunan ve açıkça tanıyan, gelişimi açısından önemli adımları atan devletlerin de bu özgürlüğüun sınırlarını koyduğu

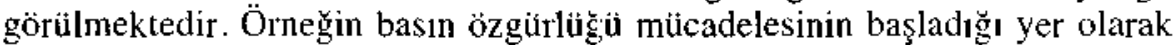
kabul edilen Íngiltere'de bu özgürlìğün sınırlanabileceği durumlar da (devleti tehlikeye sokma, genel ahlâka aykırı davranma, hukuksal bit neden olmaksızın kişilerin zararına hareket etme) ifade edilmiştir. 179l Anayasası "na "kongre, söz ve basın özgürlüğünü sınırlayan yasa yapamaz" şeklindeki maddeyi koymak suretiyle basın özgürlügünui anayasal güvenceye kavuşturan ilk ïlke olan Amerika Birleşik Devletleri'nde de, Amerikan Yüksek Mahkemesi'nin kararlarıyla bu özgürlügün "halen varolan ve açık tehlike" (present and clear danger) durumunda anayasaya aykırı olmamak kaydıyla yasayla sımırlanabileceği belirtilmiştir. ${ }^{17}$ Aynı şekilde insan haklarına ilişkin değişik uluslararası anlaşmalarda da iletişim özgürlüğüne sınırlamalar getirilmiştir. Örneğin Avrupa İnsan Hakları Sözleşmesi'nin 10. maddesi ile iletişim özgürlüğü düzenlenmiş, aynı maddenin ikinci fıkrasında

Küresel Yükselişi, Detleyenler: Larry Diamend-Marc F. Plattnet, Ankara 1995, s.72-73. Ayrica bkz., Demokrasi Nedit? s.17-18 vie Muammer Aksoy, "Türkiye'de Düşünce Özgürlüğü". Türkiye'de İnsan Haklası Semineri (9-11 Ara!ık 1968), Ankara 1970, s.126-128.

" Özgürlükletin düzenlenmesi ve sınır anmasına jlişkin olarak bkz, Fazıl Sağlam. Temel Hakların Sınırlanması ve Özii. Ankara 1982, 18-24. Basın Özgürlijğü alanında düzenleme ve sınırlama hakkında bkz.,Dönmezer, Basın Hukuku. s.70vd.i Içel s.60.6i.

${ }^{17} I_{\text {çel s. 28-29. }}$ 
ise bu özgüirlïgün sınırlanabileceği ve yaptırıma bağlanabileceği haller sıralanmıştır.

Demokrasinin iyi bir biçimde işlemesinin ve gelişmesinin önemli itici güçlerinden biri olan başnın görevlerini yerine getirebilmesi için demokrasinin gerektirdiği özgürlük anlayışından en geniş şekilde yararlanması gerekmekle birlikte basin özgürlüğ̈̈i, tek taraflı algılanmamalı, haberi verenin hakları kadar okuyucunun haber alma hakkı da dikkate alınmalı ve biri olmazsa diğerinin yarım kalacağı unutulmamalıdır. Basın özgürlügüüün en iyi biçimde sağlanması için hem haberi veren hem de alan kesimin kendi içlerinde de ayırıma tâbi tutulmaksızın, geniş bir yelpazeden bir arada düşünülmesi gerekir ve bunun için siyasi iktidara olduğu kadar basına da büyük görev düşer. Bu özgürlìgün, tüm tarafları için aynı anda anlam ifade etmesi, -menfaatlerin her zaman aynı noktada kesişmeyeceği ve sıklıkla çelişebileceği gerçeği karşısında- zor ise de basının, meslek etiģine uygun olarak görev yapması; özellikle kişilik haklarının korunması açısından özdenetimin sağlanması; siyasi iktidarın da bir yandan tarafsız kalması; öte yandan bu özgürlïgüun engellerini ortadan kaldıracak tedbirleri alması; özgürlügüi tüm tarafları için mümkün olabilecek en iyi ölçüde etkili kılmak amacıyla, kötüye kullanıldığı durumlara yönelik düzenlemeler yapması bu önemli özgürlük biçimini mümkün olduğu kadar netleştirebilir. Basın özgürlüł̆ì, öncelikle anayasal güvenceye kavuşturulmalı, kötïye kullanıldı̆̆ı hallerin tespiti titizlikle ve anayasaya aykırı olmayan yasal dïzenlemelerle gerçekleştirilmeli ve yasaların anayasaya uygunluğunu denetleyecek etkin bir yargısal mekanizma oluşturulmalıdır.

\section{II- Osmanlı Devleti’nde Basm Özgürlüğ̈üne İlişkin Dïzenlemeler}

Türkçe basının geç girdiği ve ilk matbaanın III.Ahmet döneminde açıllp, ilki 1729 'da, sonuncusu $1741^{\prime}$ de olmak ïzere 17 kitap bastırıldıktan sonra kapandığı ${ }^{18}$ Osmanlı Devleti, devlet anlayışına uygun olarak ve aynı zamanda çok uluslu yapısından kaynaklanan zorluklar dolayısıyla gücünün ve otoritesinin gerek yerli gerek yabancı basın marifetiyle içte ve dışta tehlikeye düşürülmesinin önüne geçmek için basın alanındaki düzenlemelerini esas olarak sınırlandırma şeklinde gerçekleştirdi.

${ }^{18}$ Fuat Süreyya Oral, Türk Basın Tarihi, Bịrinci Kitap, Osmanlı Imparatorluğu Dönemi, s.48-49. Bunlardan, Ibrahim Mütefertika'ya ait olan dokuzuncusunda, Avrupa'daki yönetim biçimlerinin monarşi, ariștokrasi ve demokrasi olmak üzere üçe ayrıldığı ifade edilmek suretiyle "demokrasi" sözcủğui ilk kez bir Türkçe kitapta yerini aldı (Alpay Kabacalı, Türk Basınında Demokrasi. Ankara 1994, s.6.) ki bu, basının öneminj göstermek açısından dikkate değer önemli bir örnektir. 


\section{A-Tanzimat Dönemi}

Osmanlı devlet anlayışındaki değişmenin ve modernleşmenin önemli bir aşamasını oluşturan ve Osmanlı tebaasının bazı temel haklarını sıralayan Gülhane Hatt-ı Hümayunu'nda birçok özgürlük gibi basın özgürlüğüünden de bahsedilmedi. Fermanın ilân edildiŏi tarihte (I839) Osmanlı Devleti'nde Türkçe gazete olarak, esas itibariyle devlet lehine bir kamuoyu oluşturmak maksadıyla devlet tarafından 1831'den jtibaren çıkarılan ve daha sonra yine aynı amaca yönelik olarak Fransızç, A sapça, Rumca, Ermenice ve Farsça nüshaları da yayımlanan Takvim-i Va"kayi ${ }^{19}$ den başka gazete bulunmuyordu.

İlk olarak Tanzimat hareketinin önemli bir bölümünü oluşluran "resepsiyon" çalışmaları içerisinde, 1858'de Fransa'dan alınmış olăn Ceza Kanununun 138 ve 139.maddeleri ile basına yönelik cezai düzenleme gerçekleştirildi. Buna göre, devletin emri ve ruhsatı ile açılmış matbaalarda, devlet, tebaası ve hükûmet erbabı aley ninde gazete, kitap ve zararlı evrak basmaya ve yayımlamaya cüret edenlerin bastırdıkları şeyler ellerinden alınacak: suçun derecesine göre, matbaası geçici olarak veya tamamen kapatılacak ve para cezası verilecekti. Genel ahlaka aykırı olarak alay ve eleştiri içeren yaztları ve edepsiz resimleri basan, bastıran ve yayımlayanlar da para ve hapis cezasına çarptırılacakı. Bu sırada, Tanzimat Fermaıı'nın ilân edildiği zamanki tablo az da olsa değişmiş; Türkçe gazete olarak, Takvim-i Vakayi'nin yanına devletin verdiği imtiyaz üzerine bir İngiliz (William Churchill) tarafından çıkarılan ve yarı resmi nitelik taşıyan Ceride-i Havadis ve bir de Vakayii Tıbbıye adlı bir dergi ${ }^{20}$ eklenmişti. Bu noktada belirtmek gerekir ki, Osmanlı Devleti'nde öteden beri Fransızca, Arapça, Rumca, Ermenice vb. farklı dillerde yayın yapan bir basın da bulunmakta idi."

Bu cezai düzenlemenin ardından gazete kapatma eylemi de gerçekleşti. Özel sermaye ile Agâh Efendi tarafından 1860'da çıkarılmaya başlanan Tercüman-ı Ahval ki, bu gazetede başlıca ülkenin mali sorunlarına yer veren, eğitim sistemini, devletin dış politikasını eleştiren yazılar yer almakta

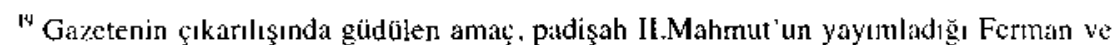
"Mukaddeme-i Takvim-i Vakayi" başlıklı özel sâyıda ifade edilmiştir. Bkz.. Hıf\%ı Topuz, I00 Soruda Başlangıçtan Bug̣ine Türk Basın Tarihi, İ:tanbul 1996.s.7.

يi Ceride-i Havadis hakkında bilgi için bkz.. Oral.s.77.79. Vakayii Tıbbiye için bkz., Bülent Varłık. "Tanzimat ve Meşrutiyet Dergıleri". Tanzimat'tan Cumlurıyet ce Türkiye Ansiklopedisi. C.I.s.112.

") Geniş bilgi için bkž. Orhan Koloğlu, "Türkçe-Dışı Basın". Tanzinıat tan Cumburiyat'c Türkiye Ansiklopedisi, C.1s.94vd. Koloğlu, Osmanlı Devieti"nin basın rejiminin çoğunlukla sadece Türkçe basıı yönelikmiş gibi değerlendirildiğini, oysa ki, basıı alanındaki düzenlemelerde Türkçe-dışı basıınıı toplum üzerindeki etkilerinin de dikkate alındı ğını ilade etmektedir. Bkz.,s.94. 
idi, $^{22}$ eggitim konusundaki olumsuzlukları ele alan bir yazı dolayısıyla 1861'de iki hafta süreyle kapatıldı. ${ }^{23}$

Basınla ilgili ilk Nizamname ise III. Napolyon döneminde çıkarılan 1852 tarihli yasa örnek alınarak yapılan 1864 tarihli Matbuat Nizamnamesi'dir ${ }^{24}$. Nizamnamenin çıkarıldı̆̆ tarihte, Osmanlı Devleti'nde başlıca dört Türkçe gazete (Takvim-i Vakayi, Ceride-i Havadis, Tercüman-1 Ahval ve Şinasi tarafından 1862 'de kurulan ve yazılarında parlamenter sistemin savunulduğu; Tercüman-1 Ahval'de olduğu gibi maliye, ekonomi, eğitim vb. alanlardaki açmazların dile getirildiği; devletin dış politikasının eleştirildiği Tasvir-i Efkâr ${ }^{25}$ ) ve diğer dillerde çıkarılan gazeteler de bulunmakta idi. Öte yandan belirtmek gerekir ki, Fransa'da 1868 yilında yani Osmanlı Devleti’nin eski düzenlemeyi aktarışından sadece dört yll sonra gazete yayını için önceden izin alma şartını kaldıran yeni bir yasa çıkarıldı ve 1881 'de yani OsmanIı Devleti'nde basın alanındaki sinırlamaların arttı̆̆ı dönemde ise basın özgürlüğ̈̈ lehine yeni bir düzenleme kabul edildi. ${ }^{26}$

Matbuat Nizamnamesi ile -siyasi nitelikli yayınlar açısından- gazete ve dergi çıkarmak, ruhsat alma koşuluna bağlandı ve başlıca devletin iç güvenliğini ve asayişini bozan bir suçun işlenmesini kışkırtan gazetelerin geçici ya da kesin; padişah ve hanedanı hakkında uygunsuz sözler kullanan; vekiller, dost ve müttefik devletlerin hükümdarları, yabancı devletlerin temsilcileri aleyhinde yazılar yazan gazetelerin bir ay süreyle kapatılacağı belirtildi. Bu kapatmalar hükümet kararıyla gerçekleştirilecekti. Bir gazete aleyhinde iki yıl içinde mahkeme kararıyla verilmiş üç hüküm bulunması durumunda da bu gazete, yine hükümet tarafindan geçici ya da kesin olarak kapatılabilecekti. Nizamname'de ayrıca dışarıda bastırılmış olup, Osmanlı Devleti aleyhinde yazılar içeren gazete ve benzeri yayınların da ülkeye sokulması yasakland. ${ }^{27}$

${ }^{22}$ Orhan Koloğlu, "Osmanlı Basını:İçeriği ve Rejimi",Tanzimat'tan Cumhuriyet'e Türkiye Ansiklopedisi, C.1, s.77.

${ }^{23}$ Topuz, Türk Basın Tarihi, s.I 1 .

${ }^{24} \mathrm{Nizamname} \mathrm{metni} \mathrm{için} \mathrm{bkz.,} \mathrm{Cevdet} \mathrm{Kudret,} \mathrm{Abdülhamit} \mathrm{Döneminde} \mathrm{Sanșür} \mathrm{II,} \mathrm{Eylül}$ 2000.s.25-41 ve Server İskit, Türkiye'de Matbuat Rejimleri, Istanbul 1939. Matbuat Kanurlan Kısmu, s.691-695.

${ }^{2}$ Koloğlu, Osmanlı Basını, s.77. Hukuku.s.25.

Fransa'da basın özgürlüğủnün gelişimine ilişkin olarak bkz.. Dönmezer, Basın

${ }^{27}$ Bu Nizamnamenir, 3.maddesi jle basın açısından yerlj yabancı ayırımını ve böylelikle bu alanda Avrupalıların kapitülasyonlardan yararlanma olanağını ortadan kaldırdığı. bu nedenle Türkçe basın tarafından olumlu karşılandığı hususunda bkz,,Orhan Koloğlu. "Osmanlı’larda Basın ve Kamuoyu”, Osmanlı Ansiklopedisi, Cilt:6, İstanbul 1994,s.]85. 
Nizamnameye 1875 'de eklenen bir madde ile de gazetelerin "ilave" adıyla yapacaklan yayınlara yönelik sınırlama getirilerek, bu ilavelerde yalnızca tevcihat, resmi bildirimler ve önemli konulara ilişkin resmi telgrafnamelerin yayımlanabileceği; zihinleri bulandıran makale ve doğru olmayan şeylerin yazılamayacağı; yasağa uyulmaması halinde bir aydan üç aya kadar kapatma cezası verileceği duizenlendi. ${ }^{28}$

1864 tarihli Matbuat Nizamnamesi'ni, basının serbesti alanını önemli ölçüde daraltan yeni bir düzenleme, Kararname-i Âli ${ }^{29}$ izledi. Geçici olarak çıkarıldığı ve çıkarılmasını gerektiren nedenler ortadan kalkar kalkmaz yürürlükten kaldırtlacağı ifade edilen, fakat 1909'a kadar yürürlükte kalan 1867 tarihli bu Kararname ile İstanbul'da değişik dillerde çıkan bazı gazetelerin, ülke çıkarlarına aykırı zararlı düşünceler ve yalan haberler yayımladı̆̆̆; asayiş ve düzenin săglanması için Matbuat Nizamnamesi hükümleri dışında hükümetçe cezalandırma işlemine ve önleyici tedbirler alınmasına karar verildiği ilân edildi ve Kararnamenin gereğ yerine getirilerek birçok gazete kapatıldi.

Devleti bu Kararnameyi çıkarmaya yönelten, Matbuat Nizamnamesi'ne karşın ülkede yayın yapan gazete ve dergi sayısının artması ve bunlarda, hükümeti eleştiren yazılarm yayımlanması (özellikle devletin Girit konusunda güttüğg̈i politikanın eleștirilmesi ${ }^{30}$ ) idi. Yani Osmanlı basını, okuyucuyu olaylar hakkında bilgilerdirme ve bir ölçüde siyasi iktidarı denetleme ve eleştirme görevini tüm olumsuzluklara rağmen yerine getirme gayreti içinde idi. Bu ise ifade özgürliigüunün basın yoluyla kullanılmasının önlenmesi yolunda daha ağır düzenlemeleri beraberinde getirdi. Nitekim, 1876'da yayımlanan bir kararname ile gazeteler için ön denetim getirildi. Kararnamede, Osmanlı basınının yazılarına fazlasıyla dikkat edildiği, çoğu kez kapatma vb. cezalar verildiği, ancak içinde bulunulan durumun önemi dolayısıyla İstanbul'da ve ülkenin her yerinde çeşitli dillerde basılan gazetelerin basilmadan önce denetimi ısulü konuldugu belirtildi. ${ }^{31}$ Ancak bu kararname fazla uzun ömürlü olmadı, ilânmda önemlì rol oynayan Mahmut Nedim Paşa'nın, görevinden alınıp yerine Mütercim Rüştü Paşa'nın sadrazam yapılmasıyla yürürlükten kaldırıldı.

Basına yönelik sınırlamalar arasında "mizah"a ilişkin olanları önemli bir yer tuttu. Osmanlı Devleti, basının kullandığı etkili bir yöntem olan ve demokratik esaslara dayanmayan bir yönetim anlayışı ile bağdaşması

\footnotetext{
${ }^{28}$ Kabacalı, Türk Basınında Demokrasi, s.26; Kudret.II.s.41.

${ }^{24}$ Bk7... Kudret, Il, s.43-44; İskit, Matbua1 Kanunları Kısmi, s.696.

.4 Koloğlu, Osmanlı Basını, s.81: Topuz,Türk Basın Tarihi. s.29; Kabaçalı. Türk Basinında Demokrasi, s.22.

${ }^{31}$ Bkz.. Kudret. Il.s.45; jskit. Matbual Kanunları Kısmı, s.698.
} 
oldukça zor olan mizahın gücünü kavramıştı. Bu nedenle özellikle Abdülaziz ve II. Abdülhamit dönemlerinde mizah gazetelerine karşı sıkı tedbirler alindt.

$\mathrm{Bu}$ tedbirler arasında özellikle $1870^{\circ}$ de Teodor Kasap tarafından çıkarılmaya başlanan ve Namık Kemal'in de yazılarının yer aldığı mizah dergisi Diyojen'in, kuruluşundan itibaren birkaç kez kapatılması ve en sonunda 1873 'de, 1867 tarihli Kararname-i Âli gereğince yayın hayatına tamamen son verilmesi: ${ }^{32}$ Teodor Kasap'ın Diyojen'in kapatılmasının ardından çıkardığı Çıngıraklı Tatar adındaki mizah dergisinin de kapatma cezası alması ${ }^{33}$; 13 Ocak 1876 'da yayımlanan bir kararla, mizah gazeteleriyle yayımlanacak resimlerin ve altlarma yazllacak ibarelerin Matbuat Idaresine verilmemesi ve buradan basılması hususunda izin alınmamasi durumunda yayımlanmalarmın yasaklandığım bildirilmesi ${ }^{34} ; 4$ Agustos 1876 'da, artık şaka ve mizah içeren yazıların yayımlanmasıma izin verilmeyeceğinin ilân edilmesi ${ }^{35}$ ve yine Teodor Kasap tarafından çıkarılmış olan Hayal adlı mizah gazetesinin, 1876 Anayasası'nın basın özgürlüğüne ilişkin 12. maddesini bir karikatür ile eleştirmesi sonucunda Teodor Kasap'ın üç yıl hapse mahkum edilmiş olması sayılabilir. ${ }^{36}$

Öte yandan II. Abdülhamit'in tahta çıkısından bir süre sonra hazırlanan Matbuat Kanunu tasanısına ilişkin meclis görüşmelerinde de en çok tartışılan konulardan biri tasarınm mizah yayınlarıyla ilgili düzenlemesi oldu. Yoğun tartışmaların ardından mizah gazetelerini yasaklayan maddeler tasarıdan çıkarıldı; ancak bu tasarı padişah tarafından beğenilmediği için yürürlüğge giremedi $^{37}$ ve padişah, $1877^{\prime}$ den itibaren hiçbir mizah gazetesine ruhsat vermedi. ${ }^{38}$

\section{B- II.Abdüilhamit Dönemi}

Basın alanındaki kısıtlamalar ve sansür, II. Abdülhamit ile birlikte artarak devam etti, hatta bu dönemin önemli bir özelliği haline geldi. Öyle

\footnotetext{
${ }^{32}$ Kabacalı, Türk Basınında Demokrasi,s.22-23; Ayrıca bkz., M.Bülent Varlık, "Tanzimattan Cumhuriyet'e Mizah", Tanzimat'tan Cumhuriyet"e Türkiye Ansiklopedisi, C.4, s.1094.

${ }^{33}$ Kabacalı, Türk Basınında Demokrași,s.25.

${ }^{34}$ Kabacal,,Türk Basınında Demokrasi, s.26: Varlık, Tanzimat'tan Cumhuriyet'e Mizah, s. $1095-1096$

${ }^{35}$ Varlık, Tanzimat'tan Cumburiyet'e Mizah,s.1096; Topuz, Türk Basın Tarihi,s.31; M.Nuri İnugur, Bastn ve Yayın Tarihi, Istanbul 1993.s.256

${ }^{34}$ Kudret,I, s.29.

${ }^{37}$ Kabacalı, Türk Basınında Demokrasi. s.46-49; Varlık,Tanzimat'tan Cumhuriyet'e Mizah, s.1096-1097:Topuz, Türk Basın Tarihi, s.34-36.

${ }^{3 k}$ Dönmezer. Basin Hukuku s.131.
} 
ki, siyasi hiçbir yanı olmayan sözcüklere dahi bir çok anlam yüklenerek, bunların ne şekilde olursa olsun kullanılması, özellikle suikast, ihtilal vb. iktidar karşıtı olaylara ilişkin yayınlar yapılması yasaklandı, dizg̣ yanlışları yüziinden gazeteler kapatıld.

Yeni bir Matbuat Nizamnarnesinin hazırlandığı, fakat yürürlüğge girmediğ̣ bu dönemde basın alanındaki ilk önemli yenilik, Osmanlı Devleti'nin ilk anayasasındaki 12 . madde oldu.

1876 Anayasası, basın özgürlüğünün özünü oluşturan ifade özgüriüğine yer vermedi" 12 maddesinde ise basm "kanun dairesinde" serbest brakt1. Anayasanm. "Tebaai Devleti Osmanivenin Hukuku Umumiyesi" kısmında basına ilişkin bir hükme yer verilnniş olması olumlu ve önemli bir gelişmedir. Ancak, bu Anayasaya örnek teşkil ettiği kabul edilen 1831 tarihli Belçika Anayasası'nın 18. maddesinde, basının özgür olduğu, sansür yoluna gidilemeyeceği yazardan, yayımcidan veya matbaacıdan teminat (depozito) istenemeyeceği açıç̧a düzenlenmiş; yazarın bilinmesi (tanınması) ve Belçika'da oturuyor olması durumunda yayımcının, matbaacının veya dağıtıcının kovuşturulamayacağı da belirtilmiştir. 1876 Anayasası 'na örnek alınan 1850 tarihli Prusya Anayasası'nın basın özgïrlüğüne ilişkin 27. maddesinde ise, her Prusyalının sözle, yazıyla, yayın yoluyla ve resimle düşüncelerini serbestçe ifade edebilme hakkına sahip olduğu; sansür konulamayacağı: basın özgürlügüne getirilecek diğer sunrlamalarm ancak kanun yoluyla olacağı hükme bağ lanmış ve böylelikle hem düşünce özgürlúğtine hem de bu özgürlügün basın yoluyla ifade edilmesine olanak sağlanmıştır. Görüldüiği üzere 1876 Anayasası'nın 12. maddesi. Belçika Anayasası'nın ilgili maddesinden çok farklıdır. Prusya Anayasası'nın 27.maddesinin sadece son kısmına benzemekteyse de, bu anayasanın "sansür konulamaz" şeklindeki ifadesi karşısında bu maddeden de önemli ölçüde farkhilaşmaktadır.

Anayasanın, "matbuat kanun dairesinde serbesttir" şeklindeki hükmii, basın özgürlüğünü yasama karşısında savunmasız bırakan bir düzenlemedir. $\mathrm{Bu}$ olumsuz durum, yasama faaliyetinin gerçekleştirilmesi sürecinde yasama meclislerinin değil, esas itibariyle padişahın etkili olduğu gerçeği karşısında daha da belirginleşmektedir.

${ }^{34}$ Bu noktada 1876 Anayasası'nın yapılışında ve ilânında önemli rol oynayan Mithat Paşa'nın hazıtlatlığ 57 maddelik anayasa tasarısında (Kanun-1 Cedid), "Osmanlıların hukuk ve vezaili"tıi düzcnleyen 13 madde arasında düşü̉nce özgürlügüne de yer verildiğini bejirtmek gerekir. Buna göre, "herkes kaalen ve kalcmen beyan-ı elkârda âzadedlir. Anciak bunu suiistimal ile asilyiş ve ahlâk-ı umumiyeyi ihlâle tasaddi edenler ber mucib-ı kanun ceza görecekierdir "Bk\%..Tarık ZaJer Tunaya. "Mithat Paşa "nm Anayasa Tasansi:Kanum-i Cedid". Tanzimat'tan Cumburıyet'e Türkiyc Ansiklope:Jisi, C.1, s.30-31. 
Fakat aynı maddenin, basını yürïtmeye karşı güvence altına almak açısından olumlu bir yenilik getirdiğini de kabul etmek gerekir. Cünkü, bu düzenleme ile artık o tarihe kadar basma idari kararla getirilmiş olan yasaklara benzer düzenlemelerin önüne geçilmektedir ${ }^{40}$.

12. madde bu haliyle de fazla uzun ömürlü olamadı, zira Anayasa, Meclis-i Umumi'nin padișah tarafından tatil edilmesiyle uygulamadan kaldırıld, ve Anayasanın, meclislerin tatil, fesih gibi bir nedenle toplanmadıkları dönemlerde, devleti ya da genel güvenliği tehlikeye düşüren ve meclisin hemen toplantıya çă̆ırılmasının mümkün olamadı ̆̆ vekiller heyetinin "anayasaya aykırı olmamak kaydıyla" verdi daha sonra meclisin vereceği karara kadar kanun hükmünde sayılmasına ilişkin 36. maddesine dayanarak yayımlanan Sıkıyönetim Kararnamesi ile de askeri hükümet, zihinleri karıştıracak yayın yapan gazeteleri kapatmaya yetkili k1lındı ${ }^{4 !}$.

$1878^{\prime}$ de, gazete ve dergileri denetlemek ve sansürden geçirmek üzere Dahiliye Nezareti'ne bağlı Matbuat-1 Dahiliye Müdürlügü içinde bir kurul oluşturuldu. Bu kurulun neyi denetleyeceği ise gizli bir yönetmelikle belirlendi. ${ }^{42}$ Böylelikle 1876 'da süreli yayınlar iç̧in getirilen ve çok kısa süre yürürlükte kalan ön đenetim uygulaması, bir kez daha getirilmiş oldu. Bazı kötü düşünce sahiplerinin yersiz eleştiri ve görüşlerine yol açacağı gerekçesiyle gazetelerde bahsi de 9 .maddesinde yasaklanan bu yönetmelikte, gazetelerde ne yazılması ve ne yazılmaması gerektiği emredilmek suretiyle de, devlet güdümü altında bir basın istemi açıkça ifade edildi.

Öte yandan, başlangıçta siyasi oImayan yayınların sansürden geçirilmesi sözkonusu değilken, 1882'de bunlar da sansür kapsamına alınd. ${ }^{43} 1901$ 'den sonra da yeni gazete ve dergi çıkarılmasına izin verilmedi. ${ }^{44}$

Bu dönemde yaşanan, bizzat basının kendisinden kaynaklanan ve basın özgürlügünü en az siyasi iktidardan gelebilecek kısıtlamalar kadar tehdit eden bir diğer olumsuzluk ise bazı gazetelerin, devletten sałladıkları çıkarlara bağlı olarak padişahın istekleri doğrultusunda yayın yapmaları oldu. Benzer şekilde, đış basında padişah aleyhine yazı yazılmasının önüne

${ }^{40} \mathrm{Bkz}$., Dönmezer, Basın Hukuku,s.130.

${ }^{41}$ Kudret, I,s.25; Iskit, Tahlil ve Tarihçe, s.52.

42 Sansür Kurulu ve gizli yönetmeliłge ilişkin geniş bilgi için bkz., Kudret, I, s.46-53; Yönełmelik için aynca bkz.,Topuz, Türk Basın Tarihi,s.37-38; lnuğur,s.262-263.

${ }^{43}$ Iskit, Tahli] ve Tarihçe, s.63; Topuz, Türk Basın Tarihi,s.36.

4 Aykut Kabacalı, "Tanzimat ve Meşrutiyet Dönemlerinde Sansür", Tanzimat tan Cumhuriyet'e Türkiye Ansiklopedisi, C.3, s.612. 
geçebilmek için de bu gazetelerden bazılarına maddi çıkar sağganması yoluna gidildi. ${ }^{4.5}$

\section{C-II.Meşrutiyet Dönemi}

II.Meşrutiyet'in ilânı üzerine yazıların sansüre gönderilmenesi ve sansür görevlilerinin gazetelere sokulmaması hususunda gazeteciler anfaşt ${ }_{1}$, th Böylece gazetelerin sansürsüz çıktığı 25 Temmuz 1908'den itibaren basın alanında kı́sa süreli bir özgürlük dönemi başladı. Meşrutiyet'in ilân edildị̣̆i zaman İstanbul'da sadece dört gazete bulunmakta iken bu özgüirlük havası içinde gazete ve dergi sayısında önemli bir artış oldu.

II.Meşrutiyet döneminin basm alanındaki önemli bir değgşikliği, Anayasanın "Matbuat kanun dairesinde serbesttir" şeklindeki 12, maddesine eklenen "Hiçbir veçhile kablettab-1 teftiş ve muayeneye tâbi tutulmaz" hükmü oldu. Böylelikle II.Abdülharnit döneminde çok sıkı bir biçimde uygulanan sansürün doğurduğu tepkiyle basının ön denetime tàbi tutulamayacağı anayasa ile güvence altına alınmış oluyordu.

Bu dönemde basın alanında yapılan bir diger önemli düzenleme ise yeni bir matbuat kanunu yapılmış olmasıdır. Yine Fransa, ancak bu kez daha liberal bir yasasıyla örnek alınarak çtkarılan 1909 tarihli Matbuat Kanunu'na ${ }^{47}$ göre, gazete çıkarmak için ruhsat alma zorunluluğu bulunmuyordu yani ihbar yeterli idi. Fakat örneģin, devletin giivenliğini bozacak, ayaklanmaya kışkırtacak yolda yayında bulunan gazeteler, açlacak dava sonuçlanıncaya kadar hükümet tarafından kapatılabilecekti. Dåvanın lehte bitmesi durumunda, sorumlu müdür kapatmadan dolayı tazminat isteme hakkma sahipti. ${ }^{48}$ Ayrıca, Heyet-i vükelâ, yabancı ülkelerde ve "eyalet-i mümtaze"de çıan gazetełırin ülke içinde yayın ve dağıtımmı yasaklayabilecekti.

Kanunun basın için nispeten rahatlama sağlayan hali fazla uzun sürmedi ve kanunda başlıca gazete imtiyazı almak için depozito şarti getirilmesi (1912), devlet memurlarının ve askerlerin siyasi yazılar yarmasının yasaklanması (1912), devletin iç ve clış güvenliğini ihlal edebilecek surette yayın yapan gazetelerin Meclis-i Vükelâ kararıyla kapatılabilnesi (1913), askeri sansür memurlarının izni olmadan ordu hareketleriyle ilgili haber yazılmaması (1914) gibi bir çok de şsişiklik yapıldı. 1919'da çıkarılan bir

\footnotetext{
${ }^{4 j}$ Topuz. Türk Basın Tarihi, s.40-44.

4) Kudret.II,s.15-17; Topuz, Türk Basen Tarihi,s.59.

${ }^{t i} 1909$ tarihli Matbuat Kanunu ve bu kanunda yapılan değişiklikler için bkz.. İskit. Matbuat Kanunlars Kısms, s.707vd.

"Kabacalı. Türk Basınında Demokrasi,s.72; liskit, Tahtil ve Tarihçe, s. 109
} 
kararname ile de Matbuat Kanunu'nun ilgili maddeleri askıya alınarak, sikıyönetim bölgelerinde her tïrlü kitap, dergi ile süreli ve süresiz yayınların sansür kurulunun izni olmadan yayımlanması yasaklandı.

II. Meşrutiyet'in ilânının yol açtığı rahatlama basın alanına da yansıdı, fakat bu dönem hem kısa sürdü, hem de çok uzun bir istibdat döneminden çıkmış olmanın rahatlığı içinde herkesin düşüncelerini dilediği gibi dile getirdiği bir süreç oldu. 31 Mart Olayı sonrasında ve özellikle İttihat ve Terakki nin iktidarını pekiştirmesinin ardından basın üzerindeki baskı arttı ve yöneten sayısı tek iken halkın ülkede olup bitenlerden basın yoluyla haberdar olmasından, devletin politikasının yine bu yolla eleştirilmesinden duyulan rahatsızlık, İttihat ve Terakki döneminde de devam etti. Bu dönemde basın, iktidar-muhalefet çekişmelerinde adeta silah olarak kullanıld. İttihat ve Terakki muhaliflerinin, seslerini duyurabilmelerinin önemli bir aracı olarak basını kullandıkları bu dönemde birçok gazete ve dergi kapatıldı.

Devletin Birinci Dünya Savaşı'na girmesiyle birlikte Ittihat ve Terakki taraftarı olan gazetelerin dışındakiler kapatıld $\imath^{49}$ ve $s ı k ı$ bir sansür uygulaması gerçekleştirildi. Savaşın ve İttihat ve Terakki hâkimiyetinin sona ermesi ile basın alanında yine bir rahatlama oldu, fakat bu da daha öncekiler gibi kısa sürdü. Nitekim, 1918'de ve sonrasında alınan tedbirler çerçevesinde, basın alanında belirleyici olan esas itibariyle özgürlük değil sinirlama oldu ve basına getirilen sinırlar ve sansür uygulaması 1923'e kadar devam etti. Bu tarihte yaymlanan TBMM İcra Vekilleri Heyeti Kararnamesi ile sıkıyönetim ve buna bağlı olarak getirilen sansür kaldırıldı.

\section{D-Sonuç}

Osmanlı basını, dönem dönem yaşanan kısa süreli olumlu hareketlilikler dışında tam anlamıyla özgür olmadı ve bunun dogal sonucu olarak da -sayısı az olmakla birlikte- okuyucu, haber alma hakkını tam olarak kullanamadı.

Fakat tüm bunlara rağmen, Osmanlı basınının, mutlakiyetçi devlet yapısının arzu ettiği güdümlü kamuoyu oluşturmaya yönelik bir basın modelinden uzak olduğunu ve böyle bir devlet biçimi lehine değil, parlamentolu ve anayasalı bir yönetim anlayışından yana özgür bir kamuoyu oluşturma görevini yerine getirmek için çaba sarfettiğini belirtmek gerekir.Gerçekten de örneğin basının denetim altına alınmasına yönelik

\footnotetext{
${ }^{19}$ Koloğlu, Osmanlı Basını, s.92.

4ı jskit. Matbuat Kanunları Kısmı, s.729: Kabacalı, Tanzimat ve Meşrutiyet Dönemlerinde Sansür,s.616; Kabacalı. Türk Basınında Demokrasi, s.94.
} 
çalışmaların, basının gelişmesinden önce başladığı Tanzimat döneminde, süreli yayın sayısı arttığı gibi, bu dönen aydınlarının, yurt içinde ve özellikle de yurt dışinda çıkardıkları gazetelerde mevcut yönetimi, devletin ekonomi, maliye. eğjtim. dış siyaset gibi önemli konulardaki politikasını eleştiren ve meşrutiyeti savunan yazılara yer verildi; resmi ya da özel olsun, gazetelerin birçoğunda Batı'daki siyasi yaşam, clevlet ve yönetim anlayışı hakkında okuyucuya bilgilenme olanağı verildi. Basın üzerindeki denetimin sıkı bir biçimde uygulandığı II. Abdülhamit döneminde de -yurt içindeki süreli yayınlar etkilerini yitirmekle birlikte- Jön Türkler tarafından yurt dışında çıkarılan gazetelerde, birbirinden farklı birçok görüşün yanı sıra parlamentolu ve anayasalı bir rejim isteği de dile getirildi.

Osmanlı básım, I. ve özellikle II. Meşrutiyet dönemlerinde ${ }^{51}$ Osmanlı kadınlarının hak arayışında da kendisinden istifade edilen önemıli bit araç oldu. Gerek kadın dergileri, gerek kadınlara yönelik ekler çıkaran veya sayfa ayıran ya da kadın yazılarına yer veren gazeteler, Osmanlı kadınlarının birçok konu ve sorun üzerinde düşüncelerini açılayabilmelerini: başta Batılı kadınlar olmak üzere dünya genelindeki kadınlarla ilgili haberlere yer vermek suretiyle de farkh kadın yaşamları hakkında bilgi ve fikir sahibi olmalarmm sağladı. ${ }^{52}$

Devlet, basının kamuoyu oluşturma ve yönlendirmedeki rolünü kavrayıp, buna göre tedbirler alırken, basın, birçok sorunun yanı sıra gerek Tanzimat döneminde getek sonrasında, basının siyasal yaşamdaki önemini ve görevini vurgulayan yazlara da yer verdi. Örnegin Tanzimat döneminin önemli gazetelerinden biri olan Tasvir-i Efkâr'da, devletin gücünün, halka götürdìgü iyi hizmetlerden doğdugu ve halkın bu hizmetlerle ilgili göruşlerine ise gazetelerin tercüman olduğu Şinasi tarafından dile getirildi.". Şinasi, böylelikle basının, bir ülkenin siyasal yaşamındaki rolüne ve kamuoyunun önemine işaret ediyordu. Benzer şekilde, Ibret teki yazılarında Namık Kemal, basının toplumsal gelişim üzerindeki rolünü vurguladı: hükümeti denetleme işlevi bulunduğunu, parlamento kadar önemli olduğunu, ülke çıkarlarına hizmet ettiğini ve bu nedenlerle özgür olması gerektiğini ifade etti. ${ }^{5-1}$

54 I.Meşrutiyet öncesindeTerakki gazetesi, kimliklerini açıklamamakla birlikte kadın mektuplarına yer verdi ve $1869^{\circ}$ da Terakki-i Muhadderat adınỏ bir kadın dergisi çıkardı. 1875 'de de Vakit Yahud Mürebbi-i Muhadderat ve Ayine adlı dergiler çlkarıldı. Serpil Çakır. Osmanlı Kadın Hareketi. Istanbul 1994 s.23 ve 25.

52 Geniş bilgi için bkz, Aynur Demirdirek. Osmanlı Kadınlarının Hayat Hakkı Arayışının Bir Hikayesi, Ankara 1993 ve Serpil Çakır, s.22vd.

${ }_{53}^{3}$ Hamza Çakır, "II.Meşrutiyete Kadar Osmanlıda Basın-lktidar İlişkileri". İstanbul Üniversitesi İletişim Fakültesi Dergisi, Sayı: 11.2001 , s. 10 l

is Topuz. Türk Basm Tarihi, s.I6. 
II. Meşrutiyet döneminde de, gazetecilerin, yaptıklan işin ciddiyetinin bilincinde olduklarını gösteren yazılar yazıldı. Örneğin 31 Mart Olayı sonrasında, uygulanan yoğun baskıya rağmen, -9 Haziran 1910'da öldürülen- Sada-yı Millet gazetesi başyazarı Ahmed Samim, yazılarında basının, kamuoyunu aydınlatma görevi olduğunu, hükümeti övebileceği gibi, gerektiğinde eleştirebileceğini de dile getirdi. ${ }^{\xi_{5}}$

\footnotetext{
${ }^{55}$ Kabacalı,Türk Basınında Demokrasi, s.73.
} 


\section{KAYNAKÇA}

Abadan, Nermin, "Basın ve Haberleşme Hürriyeti", Türkiye'de İnsan Hakları Semineri (9-11 Aralık 1968), Ankara 1970 s.89vd.

Aksoy, Muammer, "Türkiye'de Düşünce Özgürlüğgï". Türkiye de Insan Haklar: Semineri (9-11 Arallk 196,8), Ankara 1970, s.125vd.

Beetham, David -Kevin Boyle, Demokrasinin Temelleri, Çeviren Vahit Bıçak, Ankara 1998.

C. Schmitter, Philippe-Terry Lynn Karl, "Demokrasi Nedir...Ne Değildir", Çeviren:Levent Gönenç. Demokrasinin Küresel Yükselişi. Derleyenler: Larry Diamond-Marc F. Plattner, Ankara 1995,s.67vd.

Çakır, Hamza, "Il.Meşrutiyete Kadar Osmanlıda Basın-İktidar" İlişkileri", İstanbul Universitesi İletişim Fakültessi Derg̨isi, Sayı: 11,2001, s. $95 \mathrm{vd}$.

Çakır, Serpil, Osmanlı Kadın Haieketi, İstanbul 1994. 2001 .

Dahl, Robert A., Demokrasi Ưstüne, Çeviren:Betül Kadıoğlu, Ankara

Danışman, Ahmet, Basın Özgùrlüğünün Sağlanması Önlemleri, (Devletin Bası Karşısındaki Aktif Tutımu), Ankara 1982.

Demir, Vedat,Türkiye'de Medya ve Özdenetimi, İstanbuł 1998.

Demirdirek, Aynur, Osmanlı Kadınlarının Hayat Hakłı Arayışının Bir Hikayesi, Ankara 1993.

Demokrasi Nedir? Türk Demokrasi Vakfi, Ankara 1992.

Dönmezer, Sulhi, "Yine Basın Özgürlügü Uzerine”, Yeni Türkiye, $96 / 11$ s. $247 \mathrm{vd}$.

Dönmezer, Sulhi, “Basında Oto-Kontrol", İstanbul Üniversitesi Hukuk Fakültesi Mecmuası, Cilt:34, 1969, s.3vd.

Dönmezer, Sulhi,Basın Hukuku, İstanbul 1968. 
Ekşi, Oktay, “'Basın Özgürlüğ̈̈’ Diye Bir Kavram Yoktur”, Yeni Türkiye, 96/11, s.25lvd.

İçel, Kaylhan, Kitle Haberleşme Hukuku, Istanbul 1998.

İnuğur, M. Nuri, Basın ve Yayın Tarihi, İstanbul 1993.

İskit, Server, Türkiye'de Matbuat Rejimleri, İstanbul 1939.

Kabacalı, Aykut, "Tanzimat ve Meşrutiyet Dönemlerinde Sansür”, Tanzimat'tan Cumhuriyet'e Türkiye Ansiklopedisi, C.3, s.607vd.

Kabacalı, Aykut,Türk Basınında Demokrasi, Ankara 1994.

Kapani, Münci, Politika Bilimine Giriş, Ankara 1988.

Kapani, Münci, Kamu Hürriyetleri,Ankara 1993. 1999.

Keane, John, Medya ve Demokrasi, Çeviren: Haluk Şahin, İstanbul

Kılıçoğlu, Ahmet, Şeref Haysiyet ve Özel Yaşama Basın Yoluyla Saldırlardan Hukuksal Sorumluluk, Ankara 1982.

Koloğlu, Orhan, "Osmanlı Basını: İçeriği ve Rejimi" Tanzimat'tan Cumhuriyet'e Türkiye Ansiklopedisi, C.I, s.68vd.

Koloğlu, Orhan, "Osmanlı'larda Basın ve Kamuoyu”, Osmanlı Ansiklopedisi, Cilt:6, Istanbul 1994, s.147vd.

Koloğlu, Orhan, "Türkçe-Dı§̧ı Basın”. Tanzimat'tan Cumhuriyet'e Türkiye Ansiklopedisi, C.1,s.94 vd.

Kudret, Cevdet, Abdülhamit Döneminde Sansür II, Eylül 2000.

Löffler, Martin, Presserecht, Kommentar, München und Berlin 1955.

Löffler, Martin-Reinhart Ricker, Handbuch des Presserechts, München 2000. 
Oral, Fuat Süreyya, Türk Basın Tarihi, Birinci Kitap, Osmanlı İmparatorluğu Dönemi.

Özek, Çetin, Basın Özgürlügünden Bilgilenme Hakkına, İstanbul 1999.

Sağlam, Fazıl, Temel Haklarm Sınırlanması ve Özüi, Ankara 1982.

Topuz, Hıfzı, "Basında Tekelleşmeler", Türk Basınının Beş Sorunu, İstanbul 1989 , s.33vd.

Topuz, Hıfzı, 100 Soruda Başlangıçtan Bugüne Türk Basın Tarihi, İstanbul 1996.

Tunaya, Tarık Zafer, "Mithat Paşa'nın Anayasa Tasarısı:Kanun-ı Cedid", Tanzimat'tan Cumhuriyet'e Türkiye Ansiklopedisi, C.1 s.30vd.

Uluç, Güliz, "Basın ve Etik”, Istanbul Üniversitesi İletişim Fakültesi Dergisi, Sayi:11, 2001,s.83vd.

Varlık, Bülent, "Tanzimat ve Meşrutiyet Dergileri", Tanzimat'tan Cumhuriyet’e Türkiye Ansiklopedisi, C.I, s.112vd.

Varlık, M. Bülent, "Tanzimat'ıan Cumhuriyet'e Mizah" Tanzimat 'tan Cumhuriyet'e Türkiye Ansiklopedisi, C.4, s. 1092 vd. 